\title{
Digital, Special, Regular and Long Distance Learning: Under a Phenomenological First Glance
}

\author{
Valderez F. Fraga ${ }^{1,2}$ \\ ${ }^{1}$ IE-ECEX Federal University of Rio de Janeiro (Associate Professor), Rio de Janeiro, RJ, Brazil \\ ${ }^{2}$ Getulio Vargas Foundation-EBAPE (Inviting Professor), Rio de Janeiro, RJ, Brazil \\ Email: valorerh@centroin.com.br
}

Received January 2015

\begin{abstract}
This study presents and discusses trough a phenomenologic qualitative method summed up with an empirical insertion in the challenges of an education project on digital education for special, regular students and also a glace to long distance learning and teaching, in an Experimental School in Brazil. The discussions show the complexity but also the possibility of educational advances, to envision the advantages of the respect for students' differences, in parallel to educators support and the significance of the aggregation of traditional methods and modern technologies in learning situations for all possible advantages from emotional to multiple intelligences for better living conditions.
\end{abstract}

Keywords

Digital Education, Phenomenology, Special and Regular Education

\section{Introduction and Theoretical Fundaments}

In this day and age, reality is growing so complex and challenging that it sometimes leads us to cogitate if it would be possible to stop our routine rush in order to try to re-interpret in which world are we living in, at least to make an option for some minutes, to slow down, to reencounter ourselves, as well as those we almost symbolically live with. As the phenomenologist Merleau-Ponty says, trying to meet with one another as "incarnated" ([1], p. 204) persons, not as simple virtualities.

Thus, despite of all apparatus involving us all day long, places still exist for us to live together. However, their presence does not simply indicate that we live in it with others, but just the opposite. There frequently seems to be places where we are just nobody, that is: those which the French sociologist Mark Augé calls "no places" ([2], p. 105). Terms like reduction in Husserl's phenomenology ([3], p. 90) meaning the return to the essentials, are in this way at risk, by misleading people to a kind of virtual being, less humane, reduced to digital addresses through which we intend to transmit our thoughts, problems or joys reduced to mere symbols or words.

If teachers have the challenge to deal with such in our time, they also have a great opportunity to balance this 
unfortunate as well as marvelous époque of simultaneous contrasting openness and closure, when their role and/ or duty is exactly to put both conditions together, so familiarly articulated as only one complex and great wonderful new world, for humanity to live with as phenomenology expects. Also one, as phenomenology would express it, as living in such an intimate way that [4] it becomes possible, "not the body as an information machine", but in another condition: "with my body awake to the associated ones, 'the others' [...] not simply in a "zoological way” [...] but returning to philosophy” ([4], p. 17), "mixed with the world” ([1], p. 361), also in loud or "silent language of reading ([1], p. 160).” By perceiving human beings as a permanently advancing open source, man becomes the only living being with possibilities of retaking intention and consciously the world already there, towards the development of an open ended project” ([5], p. 166) including digital knowledge for human well being.

Even when technological facilities are not as yet actualized as they could be in third or emergent world nations, there still is a gain for children, youngsters, adults and students from the new ways and opportunities to acquire not only information, but knowledge and new intellectual abilities, as Gardner [6] believes possible, through such facilities by which many of them can contribute to the growth of the thinking/doing processes which would be employed constructively under such a philosophical way of dealing with others.

When Augé [2] describes such a reality as “non places”, he leads us to Merleau-Ponty reflections on language and communication, since "to communicate is sharing live relationships" ([1], p. 206) that inevitably comes to our minds as new ways of communication among humans which, by not being the traditional way, requires new abilities that are not only related to knowledge, but to technologically demanding domains, often intensively related to emotions, offering people surprisingly new ways of manifestation. These new ways bring a new ingredient to communications brought about by technology itself and by developing new thoughts and unexpected moments of emotional situations with individuals and groups as well. That dynamics is deeply related to what [7] is categorized as "emotional labor", which is as education, a kind of "face to face, voice to voice” ([7], p. 3) process serving the recognition of reality to which we emphasize the digital education itself, due not only to the electronic machines and systems attractiveness, but to new situations, which may be extremely unfamiliar to traditional school's population as some students talk about solitude, lack of a real atmosphere, since not all human senses are involved as they traditionally were.

That new virtual world also leads back to some Professor Anísio Teixeira's discussions on Brazilian duality history, different from the European and United States histories. Since their history is plain of congruence, shortly or after serious conflict, as in the USA Revolutionary War, while in Brazil the duality took place from the beginning: neither European descendents nor native, but always double, a dusty posture which he understood as "proclaimed values versus real values" [8]. That retrospect to the sixties reality where A. Teixeira was very active in Brazilian education renovation may be a strong point to reflect toward "Human Formation" by considering "consequences not only "short term results" ([5], pp. 8, 60-61) on digital endeavor times to avoid dichotomy and to invest in the concept of education as an emotional modality of labor specially in relation to poor children whose home conditions are far from computers comfort.

\section{In Terms of Method}

To illustrate the challenging routines of education, experienced situations are described and discussed below, under a qualitative approach from a phenomenological posture, that is, in search for questions and answers to phenomenological senses, towards that which they were oriented to. For example: in the case of a teacher, to his student's domain of some abilities to use new software for practical purposes, or for new knowledge as personal pleasure, or both. The significance of such an experience looks for where on "the live learning of the one who perceives with his body and with his world” ([9], p. 281) really reigns.

\section{Empirical Research}

The field research took place in a Brazilian Experimental School, attached to a higher education organization which offers students and teachers new advances in several knowledge areas for the benefit of the learning process as a whole. The school devoted itself, in addition to traditional teaching and facilities for regular students, to special students also, thus facing de current challenges from this kind of purpose. One of its objectives was advancing on digital learning, for both populations, in accordance with its Mission: to give opportunities for 
distinct students in interaction as well as through specific teaching methods to help them all.

This paper focuses mainly on special education teaching and learning at a digital lab facility, where special students with different kinds of syndromes, in accordance with medical diagnosis, some of them presenting several neurological implications, which were taken into consideration for teaching/learning, planning and psycho-pedagogical methods in search for aptness, attitudes, abilities as a means of facing daily life routines and working possibilities as well.

During two student/teachers active years under collective as well as individual learning planning at the digital lab, students began to present changes in cognitive reactions such as capacity to assist lectures, films, storytelling, and also specific mobility needs to deal with both hard and software to face tentative for the development of products which ask for elaborate and organized thinking processes. In order to exemplify the results, two "products" developed by a special student with a high degree of neurologic problems are presented as follows [10].

The first construction is a letter in MS Word, which was stated as:

\begin{tabular}{|c|}
\hline SÃO GONÇALO (the city name) \\
DEAR PAUL \\
I'LL WAIT FOR YOU SATURDAY AT HOME TO GO \\
TO THE MOVIE \\
KISSES \\
WAITING \\
NUBIA \\
\hline
\end{tabular}

The second construction is a poem, also using MS Word, as follows:

(original in Portuguese)

\begin{tabular}{|c|}
\hline Você é o sol da minha vida \\
Que ilumina, é luz do céu, os passarinhos \\
A primavera e as árvores ficam com árvores \\
Ficam com as rosas e eu gosto do ar. \\
(signature) \\
Núbia \\
\hline
\end{tabular}

(In English)

\begin{tabular}{|c|}
\hline You are the sun of my life \\
That illuminates, it's the light of the sky, the birds \\
Spring time and the trees stay with trees \\
Stay with the roses and I like the air. \\
Nubia (signature)
\end{tabular}

The main advances of experiences like this were found in the development of self-esteem and confidence for several special students, thus making the presentation of their own productions possible during interdisciplinary fairs for all, which took place at the Experimental Schools.

The School in which this case took place, installed in the same University building, offers regular third grade primary classes up to high school, simultaneously with special education. There was a computer facility there for at least four years before the beginning of this research study. However, the digital lab was first understood simply as a place where students were taken for fifty minutes a week in order to accomplish specific tasks, under the orientation and supervision of a professional digital technician. The teachers' role was reduced to observation, not participation in instruction, so seen as mere administrators to bring and take students back to their class rooms.

This study follows the implantation of a Digital Project methodology on educational capacitance of teachers, 
technicians and administrators seen as a necessity.

After the first teachers involvement, they were asked to evaluate the software before planning their classes, as well as answering a questionnaire as a means to check the adequacy between content and the digital choices, while taking into consideration the ambience, development of capacities as well as a possible wake-up attitude of 23 teachers' new needs, either in terms of regular and/or special education, that they would face in informatics [11].

Due to open question research, two instruments for self evaluation, one of them distributed by an informatics administrator [10], it was possible to find the following results:

1) "My feelings are: I wish I had more instruction!"

2) "It was of great help due to new knowledge and evaluations of the given information."

3) "It was nice to better appreciate new software and to exemplify new ways not possible in a daily routine."

4) "I guess it was a good experience since it led me to unexpected curiosity."

5) "It was possible to perceive that I can use and develop better uses of the digital facilities with my students."

6) "I will search for more useful ways to deal with the computer with my students."

The answers showed a radical change in teachers' attitudes by considering participation in the Project as a partnership with technology in the permanent challenges of teaching.

A second questionnaire complemented the research instruments. This second part, in search for the possible understanding by teachers, on the relationship of the use of technology to the advancement concerning students' emotional intelligence on their multiple intelligences [6] which was summed up with other expectations such as: pedagogical, administrative and methodological activities as a whole. Answers came up as follows:

1) "I see the use of digital facility as a motivational way of transmitting content while stimulating learning, which is beneficial.”

2) "It is a wake up for teachers, students and parents special interest. With research software, the class motivation is certainly up."

3) "The learning process now is playful, more productive and stimulates multiple intelligences."

4) "...that digital learning is trustful, with its educational fundaments; that is why it has been successful."

5) "The process is stimulating and cooperative."

6) "There is a progressive advance from the beginning, although technical limitations, once in a while, delay a better production, but the proposition is excellent."

7) "A progress is evident in terms of integration: now there is informatics with education."

8) "Participation and collaboration are bringing merits to students' task motivation.”

9) "Really important to work in Projects recovering values, interdisciplinary posture, teaching and learning for the future..."

From then on, teachers were responsible for planning activities in technology usage [12] and were supported by technicians whose knowledge was widened by including education principles in their technologies experience.

\section{Research Results}

With the research questionnaires returned from the field and summation made with the participation of one of the teachers, a very articulate professional, having a double role as a mathematics and a informatics instructor, it was possible to find that:

1) Lab activities were gained diversity. Exploratory research for example: on nutrition, biology, familiarity with chemistry, films, readings, audio books, to cite a few;

2) Phenomenological sense showed its presence by itself among teachers, students and technicians, since there was a real "mixed in the world" human team atmosphere;

3) Expectations on the Informatics Project were giving considerable return in terms of better teaching and learning processes to special students and their teachers, as well as to the other teachers and students.

After a period of this productive work, the same University assumed a parallel Long Distance Learning Project, in Higher Education. At the end of the first period of classes, there was a meeting of teachers and professors with very different profiles for a lecture on informatics and education. This author of this paper gave a lecture based on the special student letter, digital facilities and long-distance learning.

The introduction was inspired on the letter and the poem produced by the special student, presented above, 
by relating it to a film referred to in the subject letters, indeed, Love Letters, produced during the World War II, a prize-winning film, due to its relevance in many senses, from film production technology to challenging human situations. It tells a strongly dramatic story of an amnesic woman with two personalities, and a soldier unable to return her hand-written letters any more. A very sensitive story combined with composer Victor Young's touching melody, named exactly Love Letters, distributed by MCA in 1994. By the appearance of several teachers present at the event, it was easy to perceive that they were reporting on their sharing of the victory by the little special student on the writing of her first love digital letter.

After the initial emotional impact, many other important aspects of digital technology's implications on education were discussed with the large audience, such as: the impact on virtual relations and the contrasting silent communication situations, in comparison to traditional classroom dynamics, where one can hear laughs, or sad words, perceive the smell of ink paintings, teachers' alert on difficult contents, congratulations for good results at the black board, indeed human presence as a whole, to which all people were accustomed to at home, work or study situations and which is in great revolution all over the world after accessibility to informatics.

\section{Final Considerations}

Every day there are new ways of expressing one's feelings and dealing with not only study situations, but with life as whole. Consequently, no matter if special or regular, presence or long-distance education, the world is evolving fast for gratification as well as challenging people and here is where educators' mission resides: to help the flourishing of new possible talents, intelligence and reducing limitations, since people of the world are profoundly mixed. Accordingly, it seems to be the new and safest way to continue in search for new talents and knowledge, despite challenges or success or both together.

At this time, experimental studies are growing into complex methods, for educators and researchers to confront in both the Orient and Occident. The tendency to develop and help students on multiple intelligences must grow, as this paper has emphasized.

\section{References}

[1] Merleau-Ponty, M. (1971) Fenomenologia da percepção. Tradução: Reginaldo di Piero. Freitas Bastos, Rio de Janeiro.

[2] Augé, M. (1994) Não lugares. Introdução a uma antropologia da supermodernidade. Tradução Maria Lucia Pereira. Papirus, São Paulo.

[3] Edmund, H. (2008) A ideia da fenomenologia. Tradução de Artur Morão. Edições 70. Martins Fontes, São Paulo.

[4] Merleau-Ponty, M. (2013) O olho e o espírito. Tradução: Paulo Neves e Maria E. G. G. P., São Paulo, Cosac Naif.

[5] Fraga, V.F. (2009) Gestão pela formação humana: Uma abordagem fenomenológica. Manole, São Paulo.

[6] Gardner, H. (2011) Frames of Mind: The Theory of Multiple Intelligences. Basic Books, New York.

[7] Guy, M.E., Newman, M.A. and Sharon, H.M. (2008) Emotional Labor. Putting Service in Public Service. ME Sharp Inc., New York.

[8] Teixeira, A. (1962) Valores proclamados e valores reais nas instituições escolares brasileiras. Revista Brasileira de Estudos Pedagógicos, 37, 59-79.

[9] Merleau-Ponty, M. (1996) Fenomenologia da percepção. Tradução: Carlos A. R. M. Martins Fontes, São Paulo.

[10] Guimarães, C.R.A. (2002) A metodologia de projetos como prática pedagógica, e sua adesão à informática com a educação. (Dissertação de Mestrado) Universo, Niterói, Rio de Janeiro, Brazil.

[11] Almeida, F.J. (2005) Educação e Informática. Cortez, São Paulo.

[12] Cox, K.K. (2003) Informática na Educação. Autores Associados, Campinas, SP. 